Editorial

\title{
Recordando a un medico del trabajo. El Dr. Antonio Iniesta Álvarez
}

\section{Remembering an Occupational Doctor: Dr. Antonio Iniesta Álvarez}

\section{Fco Javier Sánchez Lores ${ }^{1}$}

1. Presidente Honorifico de la AEEMT

Recibido: 27-03-2020

Aceptado: 30-03-2020

Conocí a Antonio a mediados de los años 90, cuando la especialidad de Medicina del Trabajo, a pesar de ser vía MIR, duraba 3 años y no estaba incluida en el ámbito hospitalario.

Recuerdo perfectamente que, en una de las tardes de largas reuniones después del trabajo de cada día, el Dr. Javier Sanz, en aquel entonces secretario general de la Asociación Española de Especialistas en Medicina del Trabajo (AEEMT), me dijo textualmente: "He conocido a un residente que promete. Tenía alguna duda acerca de la especialidad pero creo que será un buen fichaje”.

Y no se equivocó.

Antonio, en su último año de residente, publicó varios artículos junto con médicos del trabajo ya consolidados y pronto se descubrió como un médico excelente, bien formado y con ganas de seguir haciéndolo.

Comenzó su andadura como médico del trabajo, como tantos otros en aquel tiempo, en una Mutua de Accidentes de Trabajo, en Umivale, a la par que empezó a colaborar con la AEEMT, hasta que entró en la entonces Comisión Técnica Delegada, que para muchos de nosotros era la pista de enseñanza de los entresijos de las juntas directivas y las relaciones externas con la Administración, empresas y colegas médicos.

Su siguiente paso fue como Director Médico Territorial en la Mutua de Accidentes de Zaragoza (MAZ). Con sus ganas de aprender conoció los entresijos del aseguramiento mutual, la gestión de proveedores de salud, el mundo de las incapacidades para el trabajo y el modelo reparativo español.

Cuando por ley se segregó la prevención del aseguramiento, las bases para ello en la MAZ ya estaban creadas en parte por la excelente labor de Antonio, lo que facilitó la andadura de MAS Prevención como servicio de prevención ajeno.

Acabó su etapa en el mundo de las mutuas, siendo fichado por un gran despacho de abogados, donde consolidó el servicio de prevención y por ende el servicio de medicina del trabajo.

Como médico del trabajo en primera línea, desarrolló la promoción de la salud de sus trabajadores de una manera integral, de salud integral del trabajador, llegando a conocer casi todas las variables, tanto laborales como personales y sociales, que podían influir en la salud de sus trabajadores.

Muy querido y respetado por sus "pacientes", todos los que compartíamos con él momentos de vida fuera de nuestras rutinas laborables éramos testigos de cómo les atendía por teléfono sin importarle hora o día festivo.

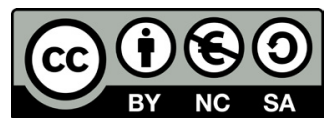

https://creativecommons.org/licenses/by-nc-sa/4.0/ 
En la AEEMT, tras pasar unos pocos años aprendiendo como he dicho al principio en la Comisión Técnica Delegada, formó parte de dos juntas directivas como vocal, aportando su talante dialogante y su conocimiento, de tal manera que pronto se le designó como representante de la Asociación en la Comisión Nacional de la Especialidad, donde abordó dos retos importantes en el desarrollo de la especialidad:

El primero fue el llamado examen MESTO, que en 2003, dada la escasez abrumadora de especialistas, dio opción a la obtención del título de especialista en medicina del trabajo a todos aquellos médicos que llevaban ejerciendo aspectos totales o parciales de la misma durante años. Recuerdo las mañanas de los fines de semana que pasamos corrigiendo exámenes en el caserón del Ministerio de Sanidad, su rigor científico, su visión humana y su humor siempre presente en las largas jornadas.

El segundo fue el nuevo programa formativo de la especialidad, que tras años de trabajo, dudas y peticiones pasaba al ámbito hospitalario, con una duración de cuatro años, igualándose con el resto de las especialidades. Antonio, junto con el resto de la Comisión Nacional de la Especialidad, luchó por obtener esta equiparación, siendo justo reconocer las horas de trabajo desinteresado que dedicó a ello.

Fue elegido Presidente de la Asociación Española de Especialistas en Medicina del Trabajo en 2007 y durante los ocho años de su mandato modernizó los estatutos, algo que la anteriores juntas presididas por mí fuimos incapaces de realizar, estableció puentes de unión con el resto de sociedades científicas de la especialidad, "los hermanos", como él decía, y mantuvo un alto nivel en congresos -Sevilla, Madrid, Valencia- que organizó con trabajo y esfuerzo, robando siempre tiempo al descanso y a la familia.

En 2018 participó en la que iba a ser su última publicación científica, la Guía de Medicina del Trabajo en Viajes, como coautor, dando una visión especial de los riesgos y trabajos en el mundo del viajero internacional en el siglo XXI.

Antonio tiene una familia a la que adoraba y cuidaba, amigos médicos y no médicos, aficiones variadas, como andar, mirar paisajes, fotografiar, ver cine y entenderlo casi como un profesional, en definitiva, ser un humanista con una enorme bondad.

En la primera semana de marzo de 2020 ese virus, que no iba a llegar a España, en el mejor de los casos solamente a uno o dos pacientes, le enganchó; un mes más tarde nos lo quitó a todos y sobre todo a su familia, Ana, Anita y Nahod.

Descansa en Paz, amigo. 